Javier S. Hidalgo*

\title{
The Duty to Disobey Immigration Law
}

DOI 10.1515/mopp-2015-0031

Abstract: Many political theorists argue that immigration restrictions are unjust and defend broadly open borders. In this paper, I examine the implications of this view for individual conduct. In particular, I argue that the citizens of states that enforce unjust immigration restrictions have duties to disobey certain immigration laws. States conscript their citizens to help enforce immigration law by imposing legal duties on these citizens to monitor, report, and refrain from interacting with unauthorized migrants. If an ideal of open borders is true, these laws are unjust. Furthermore, if citizens comply with their legal duties, they contribute to violating the rights of migrants. We are obligated to refrain from contributing to rights-violations. So, citizens are obligated to disobey immigration laws. I defend the moral requirement to disobey immigration laws against the objection that disobedience to the law is excessively risky and the objection that citizens have political obligations to obey the law.

Keywords: immigration, disobedience, injustice, authority

\section{Introduction}

Many people believe that immigration restrictions are morally permissible. They think that states have rights to exclude foreigners and deport them from their territories. This view is reflected in public opinion and policy. Most states heavily restrict immigration and these immigration restrictions are often popular. But the conventional wisdom about the permissibility of immigration restrictions might be wrong. A growing number of philosophers and social scientists defend open borders. ${ }^{1}$ They argue that immigration restrictions unjustly interfere with individual liberty and reinforce global poverty. Defenders of open immigration contend that the reasons in favor of immigration restrictions fail to

1 For instance, see: Carens (2013, ch. 11), Huemer (2010), Kukathas (2014), Caplan and Naik (2015), Oberman (2016).

*Corresponding author: Javier S. Hidalgo, Jepson School of Leadership Studies, University of Richmond, 28 Westhampton Way Jepson Hall, University of Richmond, VA 23173, USA,

E-mail: hidalgoj@gmail.com 
outweigh the moral reasons in favor of free international movement. I will refer to the view that immigration restrictions are generally unjust as the revisionary view. I have defended the revisionary view elsewhere (Hidalgo 2014).

Advocates of the revisionary view have focused almost entirely on public policy. They have argued at length that states are obligated to implement policies that permit more immigration. Yet adherents of the revisionary view have neglected to consider whether their view matters for individual ethics. Does the ideal of open borders have any implications for the obligations of individual citizens? This question acquires a special urgency if open borders turn out to be politically infeasible. Many observers, including people who endorse the revisionary view, agree that free international movement is politically untenable because most people reject open borders. Joseph Carens, the leading philosophical defender of open borders, concedes that open borders are "utopian... under current conditions" (2013, p. 296) and Chandran Kukathas argues in favor of open borders while acknowledging that free migration is "entirely infeasible" (2014, p.387). But, even if open borders are infeasible at the level of public policy, the ideal of open borders could matter for individual conduct. The truth of the revisionary view may affect how we ought to live our lives.

In this paper, I will argue that, if immigration restrictions are generally unjust, then the citizens of states that enforce these restrictions have duties to disobey the law. My argument goes like this. To an increasing extent, states are conscripting citizens to enforce immigration law by imposing legal duties on them to monitor, report, and refrain from interacting with unauthorized migrants. If the revisionary view is true, then these laws are unjust. If citizens comply with their legal duties, they contribute to violating the rights of migrants. We are obligated to refrain from contributing to rights-violations. So, citizens are obligated to disobey immigration laws. I have organized my argument as follows. In Section 2, I will explain why I believe that the revisionary view is true. In Section 3, I will argue that citizens have duties to disobey immigration law in order to avoid complicity in injustice. In Section 4, I will respond to the objection that resistance to immigration law is excessively risky and the objection that citizens have duties to obey the law. Section 5 concludes.

\section{The revisionary view}

In this section, I will briefly sketch the case for the revisionary view. To be clear, I will refrain from defending the ideal of open borders against critics. Political theorists have advanced important arguments for immigration restrictions and 
I will avoid trying to show these arguments are unsound here. My aim is merely to explain some of the reasons why I find the revisionary view to be compelling.

One influential argument for open immigration appeals to the value of freedom of movement. ${ }^{2}$ Restrictions on freedom of movement interfere with freedom of association, freedom of occupational choice, and other valuable liberties. Here is an illustration. Suppose that Linda lives in Chicago and she wants to move to Los Angeles. Employers in Los Angeles are willing to hire Linda and Linda has friends and family in Los Angeles who want to live near her. But government officials decide that they will coercively stop the residents of Chicago from moving to Los Angeles. State employees physically prevent Linda from reaching her destination and they will force her to return to Chicago if they find her in Los Angeles. ${ }^{3}$ Most people would regard this restriction on the freedom to move within the territory of the United States to be unjust. In restricting Linda's freedom of movement, public officials infringe on her freedom to associate with friends and family, pursue the occupation of her choice, explore cultural opportunities that are more accessible in Los Angeles, and advance other personal projects that require moving. State officials have weighty moral reasons to respect these freedoms. Thus, officials have strong reasons to avoid restricting Linda's freedom of movement within their state's territory.

Yet the value of freedom of movement also grounds a powerful objection to immigration restrictions. Take Linda's case again, but let's change some details. Imagine that Linda wants to move to London instead of Los Angeles. Assume that people in London would want to associate with Linda if she lived there, employers would be willing to hire her, and so on. If state officials prevented Linda from immigrating, then these officials would interfere with Linda's freedoms along with the freedoms of Britain's citizens to interact with Linda. Perhaps the British government can permissibly make Linda wait for a period of time before granting her citizenship and access to social welfare programs. But the revisionary view says that it would be unjust for the British government to deny Linda the freedom to immigrate and permanently reside in its territory. The point applies more generally. When a state restricts immigration, this state forbids foreigners from accepting employment from its citizens or associating with its citizens on their own freely chosen terms. There are weighty moral reasons against immigration restrictions in virtue of the fact that these restrictions interfere with valuable liberties.

2 Versions of this argument can be found in Carens (2013), Kukathas (2014), and Oberman (2016).

3 Freiman and Hidalgo (2016, pp. 4-6) describe a similar case in arguing that immigration restrictions infringe on valuable freedoms. 
So, adherents of the revisionary view think that there is a presumption in favor of freedom of movement. Yet they acknowledge that this presumption can be overridden. In particular, it is plausible that the reasons to respect valuable liberties can be outweighed when interfering with these liberties is necessary to protect against grave harm. For this reason, adherents of the revisionary view concede that immigration restrictions are permissible when they prevent sufficiently bad outcomes from occurring (Carens 1987, pp.260-2; Huemer 2010, pp.450-4; Oberman 2016, pp.45-50). Suppose that, if a state immediately abolished its immigration restrictions and opened its borders to foreigners, this would bring about dire consequences. Assume that open borders would cause massive overcrowding, severe environmental damage, widespread ethnic conflict, and other harms. If open borders facilitated serious harms, then the moral reasons in favor of restricting immigration may override the reasons in favor of free immigration.

But defenders of the revisionary view say that it is unlikely that most actual immigration restrictions are permissible. Contemporary immigration laws are extremely restrictive. Immigration restrictions may stop hundreds of millions of people from moving to other states. ${ }^{4}$ Many people would be able to escape severe poverty, violence, oppression, and other bad conditions if states permitted more immigration. States also routinely deport a large number of migrants, such as unauthorized migrants and failed asylum-seekers. It is doubtful whether these policies have benefits that are sufficient to justify the harms that they inflict on migrants. ${ }^{5}$ Perhaps there is some risk that abolishing immigration restrictions would cause grave harms and that we should take precautions to mitigate this risk. It only follows from this that states should gradually open their borders. States might permit more immigration every year until everyone who wants to immigrate can do so or we begin to observe seriously harmful outcomes. ${ }^{6}$ So, while adherents of the revisionary view acknowledge that some immigration restrictions are conceivably permissible, they conclude that actual immigration restrictions are generally unjust and that states should begin dismantling them.

4 For an estimate of how many people would immigrate under open borders, see: Pritchett (2006, pp.68-72).

5 Although it is hard to know what would happen if states suddenly opened their borders, we do have experience with cases in which states received large and rapid influxes of immigrants. Some social scientists argue that even sizable and rapid increases in immigration have few negative effects on net (Fetzer 2016).

6 Michael Huemer makes this suggestion (2010, pp. 452-4). 
To sum up, my view and the view of other advocates of open immigration is that states have duties to respect individual liberty and these duties require that states abolish their immigration restrictions. Even if some immigration restrictions can be justified in rare cases, most existent immigration restrictions are likely impermissible. I will assume that the revisionary view is true for the remainder of this paper.

\section{Justifying the duty to disobey}

I will now argue that, if the revisionary view is true, then citizens have duties to disobey immigration laws that regulate how citizens and migrants interact with each other. My argument begins with the observation that, when states restrict immigration in practice, they do more than authorize state employees to exclude and deport foreigners. States also conscript their citizens to help enforce their immigration restrictions. Governments impose legal duties on citizens to deny unauthorized migrants access to employment, housing, and other benefits, and to monitor migrants in order to ensure that they comply with immigration laws.

Here are some examples of laws that enlist citizens in restricting immigration:

(i) Most affluent democracies have laws that prohibit employers from knowingly hiring unauthorized migrants. Employers are often required to determine the immigration status of applicants before they consider them for employment and to fire workers if employers discover that they are unauthorized migrants (European Union Agency for Fundamental Rights 2014).

(ii) Many jurisdictions forbid private citizens from harboring unauthorized migrants. This means that landlords are prohibited from renting housing to these migrants and may be required to evict tenants if they turn out to be unauthorized migrants (Pham 2008, pp. 792-3). Certain governments have penalized private citizens for providing any form of shelter to unauthorized migrants (Jain 2010).

(iii) Banks in Britain are required to check the immigration status of customers and deny access to bank accounts to people who are unable to prove their regular status (Aliverti 2015).

(iv) Companies in the United States and most of Europe are forbidden from transporting unauthorized migrants and sometimes need to screen their passengers to satisfy this requirement (Guiraudon 2006). For example, it is illegal for airlines to fly migrants across borders if they lack the proper 
documentation and busing companies may be obligated to refuse to sell tickets to anyone that they know or believe to be an illegal alien (Pham 2008, p. 778).

(v) States now compel government employees that were formerly uninvolved in immigration enforcement to monitor and report migrants to immigration agents. Universities in the United Kingdom must monitor the immigration status of their students and report them to the government if they miss more than ten consecutive working days (Walsh 2014, p.245). Registrars are also obliged to report "sham" marriages to immigration agents if they suspect that people are getting married solely in order to secure residency in a country. Some jurisdictions in the United States require police officers to report unauthorized migrants to immigration agents.

For ease of reference, I will refer to laws like (i-v) that impose legal obligations on citizens to monitor, report, or refrain from interacting with unauthorized migrants as interaction restrictions.

Interaction restrictions are hard to justify if the revisionary view is true. Interaction restrictions are morally problematic in part because they infringe on the liberties of citizens. Yet the primary burden of interaction restrictions generally falls on unauthorized migrants. While interaction restrictions constrain the freedom of some citizens to some extent, these laws aim to entirely curtail some of the basic liberties of migrants, such as their freedom of occupational choice. So, the main reason why interaction restrictions are unjust is that they violate the rights of migrants. To explain this claim, I want to first make a more general observation about how states can violate rights. States can violate rights in at least two different ways. First, states can violate rights by prohibiting rights-holders from engaging in the activities that are protected by their rights. Second, states can forbid other people from cooperating with rights-holders to perform the actions that are protected by these rights.

Here is an example to illustrate. Suppose that the government forbids you from publishing a book that is critical of the government's policies. Imagine that the government threatens you with punishment if you try to publish this book. Obviously, the state violates your right to free speech in this case. You have a claim-right against government interference with your speech. That is, the state is under a duty to refrain from interfering with your ability to publish your book. But the government can violate your right to free speech in another way. The government can violate your rights by prohibiting other people from publishing your book. Imagine that you lack the funds to publish your book on your own and that public officials threaten other people with punishment if they attempt 
to publish your book, although the government will refrain from punishing you for publishing your book. In this example, the state violates your right to free speech even though the state avoids punishing you for exercising this right.

This example suggests that the following general principle is true: if person $\mathrm{A}$ has a claim-right to perform some action against agent $\mathrm{B}$ and A can only perform this action if some other person $C$ voluntarily cooperates with $\mathrm{A}$, then $\mathrm{A}$ has a right that $\mathrm{B}$ refrain from coercively preventing $\mathrm{C}$ from cooperating with A to perform this action. Let's call this: the cooperation principle. The cooperation principle can explain how the government can violate your right to free speech despite the fact that the government avoids punishing you for your speech. Your right to free speech means that you have a right against the government's efforts to stop other people from cooperating with you to exercise this right.

The cooperation principle helps clarify why interaction restrictions are unjust as well. As I noted in Section 2, immigration restrictions are objectionable because they interfere with occupational freedom, freedom of association, and other important liberties. The same considerations that justify rights to immigrate to a state also explain why people have rights to exercise freedom of association and occupational choice in this state. If immigration restrictions are generally unjust, then unauthorized migrants have moral rights to exercise these freedoms in the states where they reside. After all, unauthorized migrants had moral rights to immigrate in the first place, but governments simply failed to respect their rights and they were forced to immigrate without official permission. Yet the existence of moral rights doesn't depend on the government's authorization.

If unauthorized migrants have rights to occupational freedom and freedom of association, then the cooperation principle implies that they have rights against the state's attempts to coercively forbid other people from cooperating with migrants in order to exercise these rights. Interaction restrictions forbid employers from hiring unauthorized migrants, landlords from renting to them, companies from transporting them, and so on. These laws violate the rights of unauthorized migrants to occupational choice, freedom of contract and association, and perhaps other rights as well. If a law violates rights, then this is a strong reason to believe that this law is unjustified. Nonetheless, a law that violates rights may be all-things-considered justified if this law has a strong countervailing rationale. For example, it may be permissible to infringe on rights if doing so brings about a sufficiently good outcome. But it seems unlikely that interaction restrictions have a justification that is strong enough to outweigh the reasons to respect the rights of migrants. To explain why, let's briefly consider some possible justifications for interaction restrictions. 
Advocates of interaction restrictions argue that these laws are necessary to deter immigration and persuade migrants to leave. People often want to immigrate to find work. If states forbid employers from hiring unauthorized migrants, then foreigners will have less incentive to immigrate without authorization. States want unauthorized migrants to return home as well. Interaction restrictions raise the costs of residing in a territory and encourage migrants to leave the country. These laws also aim to protect citizens from competition from migrants in the housing and labor markets. Interaction restrictions penalize interactions that benefit unauthorized migrants and give employers and landlords incentives to benefit native citizens instead. Finally, some policymakers believe that certain interaction restrictions are necessary to prevent citizens from gaining unfair competitive advantages by interacting with unauthorized migrants (Pham 2008, p. 801). Businesses may gain a competitive advantage over other firms by violating the law and hiring unauthorized migrants. Employer sanctions attempt to stop businesses from securing these advantages.

These justifications for interaction restrictions crumble if the revisionary view is true. It is false that deterring immigration and compelling migrants to exit are morally desirable aims. If states lack rights to exclude outsiders in the first place, then states lack rights to use coercive measures to deter them from immigrating or to encourage them to leave. The same goes for the goal of protecting citizens from competition for jobs and housing. Advocates of the revisionary view argue that it is unjust for states to restrict the liberties of foreigners in order to insulate their citizens from competition. ${ }^{7}$ States' duties to respect the valuable liberties of foreigners typically defeat the moral reasons to secure economic benefits for their citizens. In addition, we should reject the view that it is unfair for businesses to hire people who have the right to work in a state. Perhaps the suggestion is that it is unfair for businesses to gain advantages over others by breaking the law. However, it only appears to be unfair to gain advantages by violating immigration laws if we have antecedent obligations to comply with these laws. If my argument in this paper is correct, we lack these obligations.

So, interaction restrictions violate rights and these laws lack good countervailing justifications. Therefore, interaction restrictions are generally unjust. Yet the injustice of interaction restrictions is transmitted through the behavior of private citizens. For interaction restrictions to be effective, citizens must comply with their legal obligations to report, monitor, or refrain from interacting with migrants. Interaction restrictions will fail to achieve their intended effects if citizens refuse to obey these requirements. For this reason, interaction

7 For instance, see: Huemer (2010, pp. 439-44). 
restrictions make citizens complicit in wrongdoing. Let's say that a person is complicit in wrongdoing if her actions causally facilitate the wrongdoing of another agent. ${ }^{8}$ Governments are the agents that are attempting to violate the rights of migrants in the cases that I have been describing. Public officials implement the plan of restricting the liberties of these migrants by enforcing interaction restrictions. But ordinary citizens contribute to and make the government's wrongdoing possible by complying with these laws. Interaction restrictions distribute the responsibility for violating the rights of migrants broadly among citizens.

To illustrate how citizens contribute to violating the rights of immigrants when they comply with interaction restrictions, consider the following case. Imagine that Sam owns a garment factory and he is hiring new workers. Leticia is an unauthorized migrant who is unemployed and wants a job. The state employees threaten Sam with fines if Sam knowingly hires unauthorized migrants. Government officials will forcibly take a small fraction of Sam's income if they discover that Sam has hired Leticia, although they won't punish Leticia if Sam hires her. Suppose that Sam hires Leticia and only later discovers that she is an unauthorized migrant. Sam then fires Leticia in order to comply with the law. ${ }^{9}$

Let's assume that the state's prohibition on employing unauthorized migrants is unjust in this example. The cooperation principle implies that government officials have violated Leticia's right to occupational freedom by forbidding employers like Sam from hiring her. But this rights-violation is only possible because Sam complied with the government's directives and took steps to prevent unauthorized migrants from working in his business. Sam is not merely culpable of an omission or failure to aid Leticia. He actively cooperates in the state's project of violating Leticia's rights. Sam has strong moral reasons to refrain from contributing to violating the rights of migrants. To avoid complicity in these rights-violations, he must refuse to comply with laws that require him to dismiss Leticia and other unauthorized migrants. As a result, Sam has moral reasons to disobey interaction restrictions. If these reasons are decisive, then he is morally required to disobey the law.

We can extend this basic point to interaction restrictions in general. By complying with these requirements, citizens facilitate rights-violations. Most people accept that we have strong moral reasons to avoid causing harm or

8 I take this definition of complicity from Chiara Lepora and Robert Goodin (2015, pp.41-2). Lepora and Goodin refer to this kind of complicity as "complicity simpliciter."

9 This case is realistic. Many employers fire unauthorized migrants who are workers in order to comply with immigration laws. For example, see: Bacon (2011). 
facilitating the violation of the rights of other people. Furthermore, it can be wrong to contribute to rights-violations even if you lack any intention of contributing to wrongdoing. For instance, a weapons dealer might lack any intention to cause harm, but the weapons dealer nonetheless acts wrongly by selling weapons to violent criminals who will predictably use these weapons to harm other people. Similarly, citizens may lack the intention of harming migrants or violating their rights when they comply with interaction restrictions. Perhaps they even disapprove of these laws and only obey them grudgingly. But, when citizens comply with interaction restrictions, they foreseeably contribute to violating the rights of migrants and, thus, there are significant moral reasons against this compliance.

The moral reasons to refrain from contributing to violating rights are, in general, pro tanto. That is, we have moral reasons that speak against contributing to rights-violations, although other moral considerations can outweigh these reasons. The strength of the reasons to abstain from contributing to rightsviolations varies depending on the importance of your contribution and the gravity of the rights-violation at stake. Suppose that a police officer reports unauthorized migrants to immigration authorities and this results in the deportation of these migrants. There are stringent moral reasons against the police officer's actions. Assume that, if the officer had declined to report these migrants, they would have avoided deportation. So, the officer's contribution makes a decisive difference to the outcome in which the migrants are deported. The rights at stake are also relatively weighty ones. Rights against deportation are surely among the most important rights that we possess and these rights protect urgent interests, such as our interests in living with our families. By facilitating the deportation of unauthorized migrants, the police officer contributes in a major way to violating fundamental rights. These factors explain why the officer's actions involve grave wrongdoing.

Contrast this with another case. Imagine that the owner of a small construction business complies with the law and refuses to consider hiring any unauthorized migrants, although some migrants want to work for this business. This business owner contributes to violating the rights of these migrants as well, but the contribution of this employer to rights-violations is less bad than the police officer's contribution. For one thing, other employers might be willing to hire unauthorized migrants. As a result, the business owner's decision to refrain from hiring unauthorized migrants may make only a minor contribution to setting back the interests of these migrants. Moreover, while unauthorized migrants have strong interests in finding work, they often have even weightier interests in avoiding forced deportation. So, it is plausible that the employer contributes to violating less fundamental rights than does the police officer. If 
so, then the business owner has weaker moral reasons to refrain from complying with interaction restrictions in comparison with the officer. The upshot is that, while it is pro tanto wrong to comply with interaction restrictions in general, the seriousness of this wrongdoing depends on other factors, such as the magnitude of citizens' contributions and the importance of the rights that are being violated.

To sum up, my argument for the duty to disobey immigration law goes like this:

1. Interaction restrictions are, in general, unjust because they violate the rights of migrants.

2. If interaction restrictions violate the rights of migrants and citizens comply with these requirements, then citizens contribute to rights-violations.

3. It is pro tanto wrong for citizens to contribute to rights-violations.

4. So, it is pro tanto wrong for citizens to comply with interaction restrictions.

I will refer to this as the contribution argument for the duty to disobey immigration laws. If the contribution argument is sound, then we have strong moral reasons to disobey interaction restrictions. But it is possible that these moral reasons are overridden by other considerations. I will now examine whether other considerations generally outweigh the moral reasons to disobey immigration law.

\section{Objections}

In this section, I will respond to two objections to the contribution argument.

\subsection{The risk objection}

One objection to the contribution argument is that disobedience to immigration law is risky. States threaten to punish citizens who violate interaction restrictions. Perhaps these risks of punishment release citizens from their obligations to disobey interaction restrictions. The thought here is that the duty to refrain from contributing to rights-violations is sensitive to costs to the duty-bearer. If disobedience to the law is costly because the state will punish disobedience, then it may be permissible for citizens to obey the law. In other words, this objection goes: 
1. If citizens disobey interaction restrictions, there is a significant risk that the state will impose large costs on these citizens by punishing them.

2. If there is a significant risk that states will impose large costs on citizens for disobeying interaction restrictions, then it is morally permissible for people to comply with these requirements.

3. So, it is morally permissible for citizens to comply with interaction restrictions.

Call this the risk objection. I will now argue that premises 1 and 2 of the risk objection are, at least in many cases, false.

Interaction restrictions impose legal obligations on entire populations and it is infeasible for state employees to punish more than a tiny fraction of violations. Consider employer sanctions. In the United States, only a small number of employers pay fines for hiring unauthorized workers (Calavita 1990; Pottle 2010). One reason that many employers flout the law is that the proliferation of counterfeit identity documents allows employers to claim that they were nonnegligently ignorant about the immigration status of their workers. The availability of this defense makes it difficult to prosecute employers for hiring unauthorized migrants and permits many employers to escape punishment (Massey et al. 2003, pp.118-20).

Even when states do punish employers for hiring unauthorized migrants, these employers frequently incur only minor fines for violating interaction restrictions. Again, the case of the United States is illustrative. Employers in the United States usually must pay relatively small fines for employing unauthorized migrants and it can be difficult for the state to collect these fines because employers have the right to dispute the penalties in administrative courts (Pham 2008, pp.815-16). The low probability of detection and the minor penalties attached to violations help explain why employers hire large numbers of unauthorized migrants in many jurisdictions. So, it is sometimes false that citizens incur large risks of punishment by violating interaction restrictions.

But citizens do sometimes face high risks of serious punishment if they disobey interaction restrictions. Nonetheless, it may still be wrong to comply with interaction restrictions. Morality can be demanding. Sometimes it is wrong to act in a certain way even though abstaining from acting in this way has large costs for you. Jeff McMahan gives this case: imagine that an aggressor puts a gun to your head and threatens to kill you unless you kill an innocent person (McMahan 2011, pp.113-14). Although you face enormous costs if you refuse to comply, it seems wrong for you to kill an innocent person in cases like this one. 
McMahan gives the following argument for this judgment. There is a moral difference between doing and allowing. In particular, it is morally worse to cause harm than to allow harm to occur. We are more responsible for the bad outcomes that we cause to happen than the harm that we could prevent. Consider a famous thought experiment to motivate the distinction between doing and allowing. Suppose that a surgeon can secretly kill one healthy patient and redistribute this patient's organs to five other patients who are dying of organ failure, thereby saving their lives (Thomson 1985, p.1396). Most people think that it is morally worse for the surgeon to kill the healthy patient than it is to allow the five sick patients to die of organ failure. ${ }^{10}$ If commonsense judgments about this and other similar cases are correct, then it seems morally worse to cause harm than to allow it when everything else is equal. ${ }^{11}$ Now, let's return to McMahan's case in which you face a choice between killing an innocent person and dying. If you kill an innocent person, you clearly cause harm. However, if you refuse to kill the innocent, then you allow harm to occur to someone - yourself. If it is morally worse to cause harm than it is to allow harm, then you are obligated to refrain from killing the innocent person even if this costs you your life.

While McMahan's example is obviously an extreme case, the basic structure of McMahan's argument can help clarify why citizens may be obligated to disobey interaction restrictions even if this has significant costs for them. Suppose that you are deciding whether to comply with an interaction restriction or not. If you do comply, you do something that foreseeably contributes to violating the rights of unauthorized migrants. Your compliance also protects you from the risk of state punishment. Alternatively, suppose you refuse to comply. You refrain from contributing to violating the rights of other people.

10 To be clear, the distinction between doing and allowing is not the only factor that may affect our judgments in the surgeon case or McMahan's example. Intentions play a role too. Your actions are morally worse if you intend to harm an innocent person and, as McMahan points out, this helps explain it would be wrong to kill the innocent person in the case where you must choose between killing a bystander and death. But the distinction between doing and allowing per se also seems to matter irrespective of an agent's intention. Here is an example. Imagine a runaway trolley is about to hit an innocent person who is tied to the track, but you can divert the trolley to a sidetrack. However, there is another innocent person trapped on this sidetrack. It seems wrong to divert the trolley in this case. In other words, it is morally worse to cause harm to the person on the sidetrack than it is to allow harm to befall the person on the main track, despite the fact that you don't seem to intend to harm the person on the sidetrack. This indicates that it is morally worse to cause harm than to allow harm even if you don't intend this harm.

11 The distinction between doing and allowing is controversial among philosophers. For defenses of the moral significance of this distinction, see Quinn (1989) and Scheffler (2004). 
Yet you allow the state to impose a risk of punishment on you. If there is a distinction between doing and allowing, then it can be worse to act in a manner that facilitates harm to others than to allow harm to accrue to you, even if the harm that falls on you is more severe than the harm that your actions would impose on others. Thus, it can be wrong to comply with interaction restrictions despite the fact that this disobedience is risky.

To illustrate, return to the case of Sam and Leticia. Recall that Sam has hired Leticia and discovers that she is an unauthorized migrant. The law requires Sam to fire Leticia, although suppose that Sam otherwise lacks grounds for dismissing her. Sam has two options. First, Sam could obey the law and fire Leticia. Second, Sam could refrain from firing Leticia. If Sam takes this second option, he would incur a risk that the government will detect his law-breaking and impose significant fines on him.

What should Sam do? If Sam fires Leticia, he causes harm to her in the sense that he sets back her interests in making a living and contributes to the government's plan of violating her rights. If Sam refuses to dismiss Leticia, then Sam allows the government to impose a risk of penalties on him. If there are stronger moral reasons to refrain from causing harm than to allow harm to happen, then Sam has stronger reasons to avoid firing Leticia than he does to allow risks of penalties to accrue to himself. This is the case even if the expected costs that Sam would bear are greater than the expected costs that Leticia would bear if she were fired. Assume for now that no other moral reasons bear on this case. ${ }^{12}$ It is therefore wrong for Sam to comply with the law.

To be clear, I don't claim that it is always wrong to comply with interaction restrictions. Although citizens have strong reasons for disobeying interaction restrictions, these reasons can be overcome if the consequences of this disobedience are sufficiently bad. Imagine that, if the government finds out that Sam is employing unauthorized migrants, state employees will almost certainly impose large fines on Sam's business, which would cause it to close down and result in the unemployment of all his workers. In that case, Sam's moral reasons to prevent this bad outcome from occurring can plausibly override his reasons to refrain from contributing to rights-violations. In addition, the threat of state punishment might sometimes excuse compliance with interaction restrictions without justifying it. If states credibly threaten to

12 You might say that Sam has property rights over his business and so he can do whatever he wants with it. But I am skeptical of the claim that, if you have a property right in something, then it is morally permissible to use this property however you please. At any rate, I will bracket this issue here. 
impose severe punishments on citizens who violate interaction restrictions, then states place these citizens under duress. Duress diminishes culpability for wrongdoing. This means that people who comply with interaction restrictions are less blameworthy than they would otherwise be, although their actions may still be impermissible.

\subsection{The authority objection}

Another objection to my argument is that citizens have obligations to obey the law. According to some authors, citizens have duties to obey the law and these are weighty duties that normally defeat countervailing considerations. So, if citizens have obligations to obey the law, then these obligations might defeat the moral reasons to disobey immigration laws. This argument goes:

1. Citizens have obligations to obey the law.

2. If citizens have obligations to obey the law, then these obligations generally defeat the moral reasons to disobey interaction restrictions.

3. So, it is generally impermissible for citizens to disobey interaction restrictions.

Call this the authority objection to the duty to disobey immigration law.

Many philosophers reject the first premise of the authority objection. John Simmons (1979), Michael Huemer (2012), and other philosophers argue that we should reject the view that we have content-independent duties to obey the law because all arguments for these duties are unsound. But, even if we accept that we have duties to obey the law in general, there are special reasons for doubting that we have obligations to comply with immigration law in particular. The injustice of immigration restrictions either silences or undercuts citizens' obligations to obey immigration law. To explain why, I will now show that prominent theories of political obligation are unable to explain why we are obligated to obey immigration law. ${ }^{13}$

Let's start with fair play theories of political obligation. Fair play theories of political obligation hold that citizens have obligations to obey the law in virtue of the fact that the law benefits these citizens. If a system of laws benefits citizens in a fair way, then the citizens have duties to bear their fair share of the costs of upholding this system, which requires citizens to comply with the

13 This section draws on arguments that I have defended at length elsewhere (Hidalgo 2015, pp. 11-17). 
law (Dagger 1997, chapter 5). But defenders of fair play accounts of political obligation argue that political obligations are conditional on whether a system of law is fair. After all, duties of fair play are grounded in the fairness of cooperative schemes. For example, it seems false that white citizens of South Africa were under duties of fair play to comply with laws that enforced apartheid even if these citizens benefited from these laws. This is so because these laws were egregiously unfair. When is a system of law fair? George Klosko, a prominent defender of a fair play theory of political obligation, claims that citizens only have obligations of fair play to contribute to a cooperative scheme if the benefits and burdens of this scheme are fairly distributed (2008, p. 6).

If the revisionary view is correct, then the benefits and burdens of states' cooperative schemes are massively unfair. States unjustly deny foreigners many of the rights and benefits that they are owed. If foreigners have rights to immigrate to a state, then these foreigners have rights to access and benefit from at least some of this state's institutions, such as the labor market, the court system, police protection, and other institutions. Immigration restrictions infringe on foreigners' rights to access a state's territory and benefit from this state's institutions. In this sense, immigration restrictions deny foreigners a fair share of the benefits of states' cooperative schemes. The unfairness of a cooperative scheme releases us from our obligations to contribute to this scheme or, at least, substantially weakens these obligations. So, it is plausible that the unfairness of immigration laws undercuts citizens' obligations of fair play to obey them.

Some philosophers contend that natural duties can explain why we should obey the law. Natural duties are duties that we owe to other people irrespective of our relationships or interactions with them. John Rawls argues that we have natural duties to comply with and support just institutions (1999/1971, ch. 6). Moreover, Rawls claims that natural duties can explain why we should obey the laws of a reasonably just regime. Rawls writes: "our natural duty to uphold just institutions binds us to comply with unjust laws and policies, or at least not to oppose them by illegal means as long as they do not exceed certain limits of injustice” (1999/1971, p. 308). ${ }^{14}$ Why is this? Rawls says that, if people feel free to disobey unjust laws, this will erode trust and confidence in reasonably just institutions. Christopher Wellman similarly claims that, when we disobey unjust laws, we also undermine the capacity of a state to enforce justified laws and this is a reason to refrain from violating the law (Wellman and Simmons 2005, pp. 81-4).

14 But Rawls claims that duty to obey the law only applies when the basic structure of a society is sufficiently just. 
But it is an empirical question whether disobedience to the law undermines just institutions. Wellman and Rawls advance one empirical hypothesis: disobedience to unjust laws undermines support for or the stability of legitimate regimes. While this is possible, we can't just assume that disobedience to unjust laws has this effect in general. For one thing, some forms of disobedience are unlikely to have any effects on legitimate institutions. Suppose that a landlord rents to unauthorized migrants in secret despite the fact that the law forbids her from doing so. No one else finds out about this violation of the law and the actions of the landlord don't have any discernable effects on the political institutions of her state. Natural duties fail to condemn the landlord's actions, as it is false that her disobedience has negative impacts on legitimate institutions. Perhaps disobedience to immigration law sometimes has negative effects on legitimate or reasonably just political institutions (although, again, one would need evidence to support this claim). Yet it is also plausible that disobeying interaction restrictions often advances justice on balance by helping to protect the rights of unauthorized migrants. When disobedience to the law promotes justice on balance, natural duties give us no reason to comply with these laws. ${ }^{15}$

Other theories of political obligations hold that citizens have duties to comply with the law because democratic procedures authorized these laws. One version of this argument is epistemic. This argument says that democratic procedures are reliable in that they tend to authorize justified laws. On this argument, there is a division of moral labor in that democratic governments may do better at determining which laws are justified than individual citizens. Consider an analogy with the criminal justice system. We condemn vigilantes in part because individual vigilantes are likely to be less reliable at determining

15 An objector might argue that, even if immigration restrictions are generally unjust, employers cannot hire unauthorized migrants on fair terms in the real world. Employers who hire unauthorized migrants may be unable to avoid unfairly dodging taxation and they employ workers who might lack the right to unionize. So, employers who hire unauthorized migrants take advantage of injustice and may perpetuate other injustices. But it is false that employers who hire unauthorized migrants necessarily evade taxes or prevent their workers from unionizing. For example, unauthorized migrants represent a growing fraction of the unionized workforce in the United States (Milkman 2011) and employers often do pay taxes on the labor of these migrants (Lipman 2006). Yet suppose that it is infeasible for employers to hire unauthorized migrants without flouting some justified employment laws or contributing to injustices in other ways. Now we must balance injustices. On the one hand, it may be pro tanto impermissible to violate justified employment laws. On the other hand, it also appears wrong to contribute to violating unauthorized migrants' rights to occupational freedom. It seems to me that the moral reasons to refrain from violating the rights of unauthorized migrants can defeat the reasons to comply with justified employment laws. 
the guilt of criminals than criminal courts that have elaborate procedures for delivering reliable verdicts. So, we should defer to criminal courts in order to punish criminals rather than relying on our own individual judgments, even if we have good grounds for doubting the justice of state punishment in particular cases. Some philosophers argue that we can develop a similar case for the authority of democratic governments (Estlund 2007). Democratic procedures may be more reliable on the whole than individuals and this fact gives us reasons to defer to the outcomes of these procedures.

Whatever the merits of this epistemic argument for authority in general, it is doubtful that it applies to immigration law. One reason for questioning this argument is straightforward. Democracies exclude most of the beneficiaries of immigration - foreigners - from political power. Historical experience suggests that democratic procedures are disposed to neglect the rights and interests of people who lack influence in these procedures. For example, it is plausible that democratic regimes that have excluded certain minority groups from the franchise have been more prone to enforce unjust laws with respect to these groups. The same point may apply to other vulnerable groups that are excluded from political power, such as children and future generations. If foreigners are unable to influence democratic procedures, then these procedures will likely fail to give adequate weight to the interests of foreigners. We should therefore expect democratic procedures to be less reliable with respect to immigration than they are in other domains. If democratic procedures are unreliable with respect to immigration law, then we lack reasons to defer to these procedures in this domain.

Other theories of democratic authority are proceduralist. These theories of democratic authority say that citizens are obligated to comply with the outcomes of democratic procedures in virtue of the fact that these procedures instantiate valuable properties. Thomas Christiano (2008) has developed an influential version of this view. Christiano argues that democratic procedures publicly express the equality of citizens and this property justifies an obligation to comply with the laws that this procedure authorizes. Democratic procedures institutionalize the moral requirement to treat one's fellow citizens with equal respect and we satisfy this obligation by obeying the directives of these procedures. In other words, we show our fellow citizens respect by complying with laws that are generated by democratic procedures.

But theorists of democratic authority recognize that democratic authority has limits. The authority of democratic procedures flows from the requirement to treat people with equal consideration and respect. Yet states that violate liberal rights treat their citizens with disregard and disrespect. For this reason, Christiano claims that a democratic assembly that authorizes the violation of liberal rights undercuts its own authority and releases citizens from duties to 
comply with its directives. Advocates of open borders argue that freedom of movement, including the freedom to immigrate, is a human right or, at least, an important liberty that is morally on par with other core liberal freedoms. If the right to immigrate is a human right or basic liberty, then democratic procedures express disrespect and disregard for people by significantly restricting immigration. There are resources internal to Christiano's account for arriving at this conclusion. Christiano says that basic liberal rights include freedom of occupation and "all the freedoms connected with freedom of association" (2008, p. 144). As I have noted, immigration restrictions infringe on freedom of association and occupational freedom and, of course, the same is true of interaction restrictions. If democratic procedures fail to impose political obligations on people when these procedures violate important rights, then democratic assemblies lack the power to impose political obligations on citizens to comply with interaction restrictions.

It is possible that there is some other theory of political obligation that I have neglected to discuss that can show that citizens have obligations to obey immigration law. But this survey of theories of political obligation gives us reason to conclude that citizens lack weighty obligations to obey immigration laws. The injustice of immigration restrictions seems to silence or undercut political obligations. If that's the case, then political obligations fail to weigh against our moral reasons to disobey interaction restrictions. At least, these political obligations are likely to be weak and easily overridden by our countervailing reasons to avoid contributing to violating the rights of other people. ${ }^{16}$

\section{Conclusion}

In this paper, I have argued that we have duties to disobey immigration laws. If justice requires open borders, then states are systematically enforcing unjust

16 Someone might also object to my position by arguing that people can only permissibly violate the law if they satisfy the conditions of civil disobedience, such as publicity, conscientiousness, willingness to accept punishment, and so on. In contrast, I think that it is permissible to covertly break unjust laws and evade punishment for them. While I am unable to defend this view here, I am skeptical that the conditions of traditional civil disobedience are necessary conditions for the permissibility of breaking unjust laws. For arguments that disobedience to the law can be permissible even if it fails to satisfy the conditions of traditional civil disobedience, see: A. John Simmons (2003) and Huemer (2012, pp. 164-6). Henry Thoreau, Mohandas Gandhi, and other paragons of civil disobedience may have also rejected the view that law-breaking is only justified if disobedients willingly accept punishment and demonstrate fidelity to the law. For evidence of this possibility, see Lyons (1998). 
immigration laws. States try to compel citizens to share complicity in the injustice of immigration restrictions. To avoid complicity in wrongdoing, citizens are obligated to violate immigration laws. Furthermore, citizens' moral reasons to refrain from contributing to violating the rights of foreigners are, in general, undefeated by countervailing considerations. Therefore, citizens are often morally required to disobey immigration laws.

I have, in this way, answered the question of whether the ideal of open borders affects the obligations of individuals that I posed in the introduction of this paper. Perhaps a policy of open borders is infeasible and it is unlikely that states will abolish their immigration restrictions in the near term. Nonetheless, the ideal of open borders matters for individual action. In his famous essay on civil disobedience, Henry Thoreau claimed that we have duties to disobey unjust laws. Thoreau argued that, if "the machine of government...requires you to be the agent of injustice to another, then, I say, break the law. Let your life be a counter-friction to stop the machine. What I have to do is to see, at any rate, that I do not lend myself to the wrong which I condemn” (2004/1849, pp. 315-16). I have similarly argued that citizens must refuse to lend themselves to the wrong that advocates of the revisionary view condemn. Our lives should be counterfrictions to the injustice of immigration restrictions.

Acknowledgments: I would like to thank two anonymous reviewers and the guest editors for their helpful comments and suggestions. In addition, I would like to thank Jessica Flanigan, Ryan Davis, Richard Dagger, Daniel Waxman, Natasha Basu, and audiences at Georgetown University, Oxford University, and the University of Richmond for their assistance in improving this paper.

\section{References}

Aliverti, A. (2015). "Enlisting the public in the policing of immigration", British Journal of Criminology 55(2): 215-30.

Bacon, D. (2011). "Undocumented immigrants stand up to Chipotle”, Race, Poverty, and the Environment 18(1): 13-14.

Calavita, K. (1990). “Employer sanctions violations: toward a dialectical model of white-collar crime”, Law \& Society Review 24(4): 1041-69

Caplan, C. and Naik, V. (2015). "A radical case for open borders", in B. Powell (ed.). The Economics of Immigration. New York: Oxford University Press, pp. 180-209.

Carens, J. (1987). “Aliens and citizens: the case for open borders", Review of Politics 49(2): 251-73.

Carens, J. (2013). The Ethics of Immigration. New York: Oxford University Press.

Christiano, T. (2008). The Constitution of Equality: Democratic Authority and Its Limits. New York: Oxford University Press.

Dagger, R. (1997). Civic Virtues. New York: Oxford University Press. 
Estlund, D. (2007). “On following orders in an unjust war”, Journal of Political Philosophy 15(2): 213-34.

European Union Agency for Fundamental Rights (2014). "The criminalisation of migrants in an irregular situation and of persons engaging with them", http://fra.europa.eu/sites/ default/files/fra-2014-criminalisation-of-migrants-0_en_0.pdf (accessed 29 July 2015.

Fetzer, J. (2016). Open Borders and International Migration Policy: The Effects of Unrestricted Immigration in the United States, France, and Ireland. New York: Palgrave Macmillan.

Freiman, C. \& Hidalgo, J. (2016). “Liberalism or immigration restrictions, but not both”, Journal of Ethics and Social Philosophy 10(2): 1-22.

Guiraudon, V. (2006). “Enlisting third parties in border control”, in M. Caparini and O. Marenin (eds.). Managing Borders in a Globalized Word. Geneva: Geneva Centre for the Democratic Control of Armed Forces, pp.79-97.

Hidalgo, J. (2015). “Resistance to unjust immigration restrictions”, Journal of Political Philosophy 23(4): 450-470.

Hidalgo, J. (2014). “Freedom, immigration, and adequate options”, Critical Review of International Social and Political Philosophy 17(2): 212-234.

Huemer, M. (2010). “Is there a right to immigrate?", Social Theory and Practice 36(3): 429-61.

Huemer, M. (2012). The Problem of Political Authority: An Examination of the Right to Coerce and the Duty to Obey. New York: Palgrave Macmillan.

Jain, E. (2010), “Immigration enforcement and the harboring doctrine”, Georgetown Immigration Law Journal 24(2): 147-88.

Klosko, G. (2008). Political Obligations. New York: Oxford University Press.

Kukathas, C. (2014). “The case for open immigration”, in A.I. Cohen and C. Heath Wellman (eds.). Contemporary Debates in Applied Ethics. Malden and Oxford: Wiley Blackwell, pp. 376-88.

Lepora, C. and Goodin, R. (2015). On Complicity and Compromise. New York: Oxford University Press.

Lipman, F. (2006). “Taxing undocumented immigrants”, The Tax Lawyer 59(3): 813-66.

Lyons, D. (1998). “Moral judgment, historical reality, and civil disobedience”, Philosophy \& Public Affairs 27(1): 31-49.

Massey, D., Durand J., and Malone N. (2003). Beyond Smoke and Mirrors: Mexican Immigration in an Era of Economic Integration. New York: Russell Sage Foundation.

McMahan, J. (2011). Killing in War. New York: Oxford University Press.

Milkman, R. (2011). “Immigrant workers and the future of American labor”, ABA Journal of Labor \& Employment Law 26(2): 295-310.

Oberman, K. (2016). “Immigration as a human right”, in S. Fine and L. Ypi (eds.). Migration in Political Theory: The Ethics of Movement and Membership. New York: Oxford University Press, pp. 32-56.

Pham, H. (2008). “The private enforcement of immigration laws”, Georgetown Law Journal 96: 777-825.

Pottle, D. (2010). “Federal employer sanctions as immigration federalism”, Michigan Journal of Race and Law 16(1): 107-110.

Pritchett, L. (2006). Let Their People Come: Breaking the Gridlock on Global Labor Mobility. Washington, DC: Brookings Institution Press.

Quinn, W. (1989). “Actions, intentions, and consequences: the doctrine of doing and allowing”, Philosophical Review 98(3): 287-312. 
Rawls, J. (1999/1971). A Theory of Justice. Cambridge, MA: Harvard University Press.

Scheffler, S. (2004). "Doing and allowing”, Ethics 114(2): 215-39.

Simons, A.J. (2003). "Civil disobedience and the duty to obey the law", in R.G. Frey and C. Wellman (eds.). Blackwell Companion to Applied Ethics. Oxford: Blackwell, pp.50-61.

Simmons, A.J. (1979). Moral Principles and Political Obligations. Princeton, NJ: Princeton University Press.

Thomson, J. (1985). “The trolley problem”, The Yale Law Journal 94(6): 1395-415.

Thoreau, H. (2004/1849). "Civil disobedience”, in J.T. Wren, D. Hicks, and T. Price (eds.). Traditional Classics on Leadership. Northampton, MA: Elgar Publishing, pp. 310-24.

Walsh, J. (2014). "Watchful citizens: immigration control, surveillance and societal participation”, Social \& Legal Studies 23(2): 237-59.

Wellman, C. and Simmons, A.J. (2005). Is There a Duty to Obey the Law?. New York: Cambridge University Press. 